\title{
KINITEC DESCRIPTION OF SODIUM BEHAVIOR IN SOME AFFECTED AND NON-AFFECTED SOILS BY SALTS
}

\author{
Hazim M. Ahmed Einas Y. Yousif \\ Mosul University, College of Agric. and Forestry / Dept. of Soil and Water \\ Resources. \\ Emai1:Hazim572000@yahoo.com
}

\begin{abstract}
This study included different soil locations around Mosul city representing non salt affected soils, and around Basrah city representing salt - affected soil. The aim of this study is to show the behavior of sodium due to first order and diffusion equations, using miscible displacement at different times (10, 20, 30, 60, 90, 120, $180,360,480,600,720$ minute). The results indicate that the solubility and release of sodium decreases with time, but according to kinetic concept the cumulative of sodium solubility increased in the two type of soils study. However, salt affected soils showed more solubility and release of sodium than the non-salt affected soils. While the diffusion equation gave the best description of sodium solubility depending on the coefficient determination and standard error. Selectivity coefficient of Gapon due to the chemical concept $\mathrm{K}_{\mathrm{G}}$, thermodynamic concept $\mathrm{K}_{\mathrm{G}}{ }^{-}$ and sposito concept $\mathrm{K}_{\mathrm{G}}{ }^{=}$were also examend which showed that the values $\mathrm{K}_{\mathrm{G}}, \mathrm{K}_{\mathrm{G}}{ }^{-}$ decreased with time, while $\mathrm{K}_{\mathrm{G}}=$ values increased over time.

Key words : Gapon equation, SAR, adj SAR, kinetic , thermodynamic.
\end{abstract}

Receved:3/4/2019, Accepted:10/10/2019

\section{INTRODUCTION}

Selectivity coefficient of Gapon $\left(\mathrm{K}_{\mathrm{G}}\right)$ represents the tendency of linear relationship between SAR( sodium adsorption ratio ) - ESR ( exchangeable sodium ratio) when applied on affected soils and non- affected soils by salts, this coefficient was used to control the behavior of sodium through the two parameters as mentioned above, which influenced by some soil properties including concentration of electrolytes, clay minerals, organic colloids, sodium in both solid and liquid phase of soil ( Jurinak et al., 1984 and Amrhien and Suarez ,1991 ). So the study of ion selectivity descripe the interaction between positive ion and surface exchange and water. It is also considered as an approach to understanding the movement of soluble components within the soil which represent surface chemistry of soils (Thomas, 1977). The Gapon equation is one of the most applied equation, especially in salt affected soils it was then developed by USA salinity Laboratory by inserting magnesium into both end of the equation and the regression value of linear relationship between SAR-ESR express the selectivity coefficient of Gapon (Paliwal and Gandhi, 1976) and (Farahmand et al., 2009 ). Thus, recent studies have used the kinetic concept in the description of many interaction that occur between the liquid phase and the exchange surface through using kinetics equation, but the preference between them depends statistically on the determination coefficient $\mathrm{R}^{2}$ and standard error SE (Ogwada and Sparks, 1986 ). There are many techniques used to study kinetic approach of sodium such as miscible displacement ( Sparks et al., 
$1980 \mathrm{~b}$ ). There are some disadvantage in Gapon equation when was using to descripe the exchange between $\mathrm{Na}^{+}-\mathrm{Ca}^{++}$on the solid phase of soil, according to ( Sposito, 1977 ) the concept of mole fraction were used to calculate the activity of exchange surface.

\section{MATERIALS AND METHODS}

Various locations were choosen around Mosul city (Gogjali , Taharawa , Bartella , Karamlease, Al-Abbasiah, Khursibat, Filfeal, Badoosh, Salamiah, Hamdaniah ) represent soils non-affected by salts, and another locations around Basrah ( Hamdan , Al-Fao , Abu-Alkaseeb ) represent soils affected by salts. Soil samples were drying and sieved by $2 \mathrm{~mm}$ sieves in order to be ready for laboratory analysis. Some physical and chemical properties were estimated as shown in table (1 and 2 ) according to the methods given in (Carter and Gregorich , 2008 and Rowell , 1996 and Tandon, 1999). So miscible displacement was used to study the Kinetic approach of sodium, and sodium ion was selective using plastic columns with dimentions ( $15 \mathrm{~cm} \mathrm{~L}, 4 \mathrm{~cm}$ diameter ), $20 \mathrm{gm}$ of soil was putted in each column, soil lifted to balance with distilled water for 24 hours, different time were used as follows $10,20,30,60,90,120,180,240,360,480,600,720$ minute. The extract was then collected from the soil column at each time to estimate. Both calcium and magnesium were determination by titration with versenate solution $0.01 \mathrm{M}$, and sodium by flame photometer according to Sparks et al., $1980 \mathrm{~b}$. So the diffusion equation was to descripe the solubility of sodium using mathematical formula as follows:

$$
\mathrm{C}_{\mathrm{t}}=\mathrm{C}_{\mathrm{o}}+\mathrm{Kt}^{1 / 2}
$$

$\mathrm{C}_{\mathrm{t}}$ : conc.of sodium at limited time.

$\mathrm{C}_{\mathrm{o}}$ : conc.of sodium at zero time.

$\mathrm{t}^{1 / 2}:$ time

$\mathrm{K}$ : rate coefficient of sodium solubility. 
Table (1): Some physical and chemical properties of study soils

\begin{tabular}{|c|c|c|c|c|c|c|c|c|}
\hline \multirow{2}{*}{ locations } & \multirow{2}{*}{$\mathrm{pH}$} & \multirow{2}{*}{$\begin{array}{c}\text { EC } \\
\text { ds.m }{ }^{-1}\end{array}$} & \multirow{2}{*}{$\begin{array}{c}\text { organic } \\
\text { matter } \\
\mathrm{gm} \cdot \mathrm{kg}^{-1}\end{array}$} & \multirow{2}{*}{$\begin{array}{c}\mathrm{CaCO}_{3} \\
\mathrm{gm} \cdot \mathrm{Kg}^{-1}\end{array}$} & \multicolumn{4}{|c|}{ Soil particles gm. $\mathrm{Kg}^{-1}$} \\
\hline & & & & & clay & silt & sand & texture \\
\hline Gogjali & 7.57 & 0.21 & 11.68 & 188.2 & 342 & 372 & 286 & Clay loam \\
\hline Taharawa & 7.57 & 0.22 & 18.91 & 193.1 & 291 & 403 & 306 & Clay loam \\
\hline Bartella & 7.66 & 0.21 & 7.20 & 194.6 & 441 & 322 & 237 & Clay \\
\hline Karamlease & 7.62 & 0.25 & 28.53 & 220.3 & 391 & 323 & 286 & Loam clay \\
\hline Abbasiah & 7.65 & 0.16 & 17.87 & 256.5 & 242 & 422 & 336 & Loam \\
\hline Khursibat & 7.55 & 0.23 & 21.30 & 270.8 & 392 & 422 & 186 & Silty clay loam \\
\hline Filfeal & 7.57 & 0.19 & 22.34 & 168.2 & 366 & 297 & 337 & Clay loam \\
\hline Badoosh & 7.62 & 0.18 & 10.30 & 294.2 & 366 & 448 & 186 & Silty clay loam \\
\hline Sallamiah & 7.56 & 0.37 & 61.21 & 140.3 & 372 & 352 & 276 & Clay loam \\
\hline Hamdaniah & 7.62 & 0.20 & 24.41 & 231.6 & 316 & 398 & 286 & Clay loam \\
\hline Hamdan & 7.60 & 1.64 & 20.39 & 62.6 & 341 & 422 & 237 & Clay loam \\
\hline Al-fao & 7.00 & 13.76 & 25.89 & 109.0 & 391 & 323 & 286 & Clay loam \\
\hline Al-Seebah & 7.20 & 3.77 & 22.70 & 210.9 & 241 & 473 & 286 & Loamy \\
\hline Abu- Al-Khaseeb & 7.34 & 5.98 & 31.00 & 137.3 & 391 & 273 & 336 & Clay loam \\
\hline
\end{tabular}

Table (2): soluble cations and anions in the studies soils

\begin{tabular}{|c|c|c|c|c|c|c|c|}
\hline \multirow{2}{*}{ Locations } & \multicolumn{5}{|c|}{$\begin{array}{c}\text { Cations } \\
\text { mmol. } I^{-1}\end{array}$} \\
\cline { 2 - 8 } & $\mathrm{Ca}^{++}$ & $\mathrm{Mg}^{++}$ & $\mathrm{Na}^{+}$ & $\mathrm{K}^{+}$ & $\mathrm{HCO}_{3}^{-}$ & $\mathrm{Cl}^{-}$ & $\mathrm{SO}_{4}^{=}$ \\
\hline Gogjali & 1.50 & 1.42 & 0.31 & 0.21 & 4.40 & 1.53 & 1.83 \\
\hline Taharawa & 2.31 & 1.50 & 0.31 & 0.30 & 4.85 & 2.17 & 1.64 \\
\hline Bartella & 1.53 & 2.11 & 0.17 & 0.23 & 3.50 & 1.46 & 1.42 \\
\hline Karamlase & 1.75 & 1.33 & 0.17 & 0.46 & 4.12 & 1.58 & 2.80 \\
\hline Abbasiah & 1.91 & 1.20 & 0.13 & .0 & 3.75 & 1.50 & 1.85 \\
\hline Khursibat & 1.62 & 1.45 & 0.37 & 0.17 & 4.15 & 2.55 & 2.40 \\
\hline Filfeal & 1.67 & 1.37 & 0.17 & 0.12 & 3.85 & 2.13 & 2.48 \\
\hline Badoosh & 1.82 & 0.97 & 0.21 & 0.22 & 3.20 & 2.20 & 2.63 \\
\hline Sallamiah & 1.90 & 1.82 & 0.17 & 0.71 & 4.35 & 22.34 & 2.99 \\
\hline Hamdaniah & 1.55 & 1.46 & 0.19 & 0.41 & 4.27 & 1.72 & 1.99 \\
\hline Hamdan & 2.21 & 1.81 & 13.47 & 0.25 & 5.73 & 10.31 & 0.36 \\
\hline Al-Fao & 12.33 & 4.73 & 52.17 & 1.69 & 3.70 & 20.64 & 1.72 \\
\hline Al-Seebah & 10.64 & 6.25 & 37.82 & 2.71 & 4.25 & 9.12 & 1.25 \\
\hline $\begin{array}{c}\text { Abu- Al- } \\
\text { Khaseeb }\end{array}$ & 11.26 & 5.19 & 27.39 & 3.10 & 4.12 & 9.56 & 0.94 \\
\hline
\end{tabular}




\section{RESULTS AND DISCUSSION}

\section{Kinetic $K_{G}$ according chemical thermodynamic and sposito concept:}

The theoretical approach of kinetic concept is based on the rate of reaction, which is in a state of proportion with the concentration of reactant substances and the substances resulting from the reaction, this rate represents the differentiation concentration of matter with time $\mathrm{r}=\frac{d c}{d t}$ Therefore, the study of kinetics aims to obtain a sufficient information about the behavior and rate of reaction which is added to the knowledge of the change in concentration of reactant and resultant substances over time as well as the effect of temperature on the rate and mechanism of reaction (Goyal and Rani , 2011 and Sparks , 1989). Results showed from the table (3) that the selectivity coefficient of Gapon in salt affected soils which affected by the concentration of sodium in soil solution, rate of solubility, desorption, temperature. The table (3) shows that the values of Gapon selectivity coefficient according to the chemical concept were low in the first time indicated by value $\left(0.16,0.16,0.17 \mathrm{~L}_{\mathrm{mol}}{ }^{-1}\right)$ at times $(10,20,30$ minute $)$ for Karamlease soil. This behavior affected by sodium adsorption ratio in the equilibrium solution, whose values were high because the $\mathrm{K}_{\mathrm{G}}$ values were decrease, but these values increase over time which reached to ( 48.83 ).

Table (3): Kinetic approach of Gapon constant due to chemical, thermodynamic, sposito concept in some soil non-affected by salts

\begin{tabular}{|c|c|c|c|c|c|c|c|c|c|}
\hline \multirow{2}{*}{$\begin{array}{l}\text { Time } \\
\text { minute }\end{array}$} & \multicolumn{3}{|c|}{$\begin{array}{l}\text { Karamlease } \\
\text { L.mol }^{-1}\end{array}$} & \multicolumn{3}{|c|}{$\begin{array}{l}\text { Khursibat } \\
\text { L.mol }^{-1}\end{array}$} & \multicolumn{3}{|c|}{$\begin{array}{l}\text { Badoosh } \\
\text { L.mol }{ }^{-1}\end{array}$} \\
\hline & $\mathrm{K}_{\mathrm{G}}$ & $\mathrm{K}_{\mathrm{G}^{-}}^{-}$ & $\mathrm{K}_{\mathrm{G}}=$ & $\mathrm{K}_{\mathrm{G}}$ & $\mathrm{K}_{\mathrm{G}^{-}}^{-}$ & $\mathrm{K}_{\mathrm{G}}=$ & $\mathrm{K}_{\mathrm{G}}$ & $\mathrm{K}_{\mathrm{G}^{-}}^{-}$ & $\mathrm{K}_{\mathrm{G}}=$ \\
\hline 10 & 0.16 & 0.11 & 0.58 & 0.04 & 0.03 & 0.93 & 0.07 & 0.19 & 0.63 \\
\hline 20 & 0.16 & 0.11 & 0.58 & 0.06 & 0.04 & 0.84 & 0.11 & 0.28 & 0.52 \\
\hline 30 & 0.17 & 0.11 & 0.55 & 0.08 & 0.06 & 0.81 & 0.13 & 0.31 & 0.45 \\
\hline 60 & 0.18 & 0.12 & 0.53 & 0.08 & 0.06 & 0.77 & 0.14 & 0.34 & 0.44 \\
\hline 90 & 0.19 & 0.12 & 0.47 & 0.09 & 0.06 & 0.72 & 0.14 & 0.34 & 0.44 \\
\hline 120 & 0.19 & 0.13 & 0.46 & 0.11 & 0.07 & 0.67 & 0.15 & 0.35 & 0.42 \\
\hline 180 & 0.23 & 0.13 & 0.46 & 0.11 & 0.08 & 0.66 & 0.15 & 0.36 & 0.42 \\
\hline 240 & 0.20 & 0.13 & 0.43 & 0.13 & 0.07 & 0.59 & 0.17 & 0.34 & 0.42 \\
\hline 360 & 0.24 & 0.16 & 0.42 & 0.16 & 0.07 & 0.52 & 0.16 & 0.36 & 0.38 \\
\hline 480 & 0.27 & 0.17 & 0.42 & 0.17 & 0.08 & 0.37 & 0.17 & 0.34 & 0.39 \\
\hline 600 & 0.31 & 0.18 & 0.40 & 0.17 & 0.09 & 0.41 & 0.19 & 0.33 & 0.37 \\
\hline 720 & 0.33 & 0.21 & 0.41 & 0.16 & 0.09 & 0.40 & 0.19 & 0.30 & 0.34 \\
\hline
\end{tabular}


at the last time of experiment. The low values of $\mathrm{K}_{\mathrm{G}}$ indicated that these soils having low capacity to adsorped sodium against to salt affected soils, The higher values reflect the tendency of $\mathrm{K}_{\mathrm{G}}$ values were decrease, but these values increase over time which reached to ( 48.84 ) at the last time of experiment. The low values of $\mathrm{K}_{\mathrm{G}}$ indicated that these soils having low capacity to adsorped sodium against to salt affected soils, The higher values reflect the tendency of soils to adsorb sodium ( Abdul-Ghafoor et al. , 2004 ). As for the Gapon constant $\mathrm{K}_{\mathrm{G}}$ according to thermodynamic concept, it is clear that the three soils ( Karamleas, Khorsibat, Badoosh ) with $\mathrm{K}_{\mathrm{G}}$ values are low $(0.11,0.03,0.19)$ in the soils above respectively. But these values increase with the end of time to reach $(0.21,0.09$, $0.30)$ as a result of SAR from low values to high values up to the last time. When we are consider the Gapon constant according to the concept of Sposito the table ( 3 ). show that the $\mathrm{K}_{\mathrm{G}}$ in the three soils behaved reversible, meaning that the $\mathrm{K}_{\mathrm{G}}{ }{ }^{2}$ values were high in the first time $(0.58,0.93,0.63)$ in the three soils respectively then the $\mathrm{K}_{\mathrm{G}}=$ were reduced as time progresses to reach $(0.41,0.40,0.34)$. These high values of $\mathrm{K}_{\mathrm{G}}=$ indicate clearly, exchange sodium ratio ( ESR ) of the solid phase exceeds the SAR in the liquid phase in the first time, and then this state was reversibly to decrease the $\mathrm{K}_{\mathrm{G}}=$ values with increasing in the selectivity for these soils to calcium and magnesium against sodium (Farahmand et al. , 2009 ). Soils affected salts ( Al-Fao,Al-Seebah, Abu-Alkhaseeb ) were show a difference in the values of $\mathrm{K}_{\mathrm{G}}, \mathrm{K}_{\mathrm{G}^{-}}, \mathrm{K}_{\mathrm{G}}{ }^{=}$( table 4 ). Where's $\mathrm{K}_{\mathrm{G}}$ and $\mathrm{K}_{\mathrm{G}}{ }^{-}$values reached to ( 48.83 , $37.80)$ and $(12.44,26.72)$ and $(9.33,19.40)$ in the three soils respectively. According to chemical and thermodynamic concept When tracking the behavior of $\mathrm{K}_{\mathrm{G}}$ values in these soils, we find that there is a difference in $\mathrm{K}_{\mathrm{G}}$ values of $\mathrm{K}_{\mathrm{G}}, \mathrm{K}_{\mathrm{G}}{ }^{-}$, $\mathrm{K}_{\mathrm{G}}{ }{ }$. The values of $\mathrm{K}_{\mathrm{G}}$ and $\mathrm{K}_{\mathrm{G}}{ }^{-}$increase in the three soils with increasing time of experiment, however in the three soils, the values of $\mathrm{K}_{\mathrm{G}}$ and $\mathrm{K}_{\mathrm{G}}{ }^{-}$in $\mathrm{Al}-\mathrm{Fao}$ soil according to chemical and thermodynamic concept are superior to the soil of AlSeebah and Abu-Alkhaseeb as indicated by high values ( 48.83, 29.36, 32.83) soils respectively. The superiority of ESR values on SAR in these times and $\mathrm{K}_{\mathrm{G}}$ begin to decrease with time to reach $(0.35,0.67,0.50)$ in the three soils at the last time 720 minutes respectively.

\section{Kinetics approach of sodium:}

The Kinetics of chemical reactions considered one of the concept of physical chemistry because they deal with the rate of interactions which depend on the concentrations of substances involved in the reaction. The rate of reaction is expressed by the rate of change in the concentration of reactants or resultants for time, this is why chemical reaction occur in different stage ( Sparks , 1989). In order to apply this approach on the study soils to determine the rate coefficient of sodium solubility using Kinetic equations. The table ( 5 ) shows that the coefficient solubility rate of sodium according to the slope of first order and diffusion equations have differed and varied between increasing and decreasing within the soils, affected or non-affected by salts. The highest rate solubility ( 1.14 min. $\left.{ }^{-1}\right)$ was recorded in the Al-Abbasiah soil, while the lowest value of this coefficient ( 0.04 min. ${ }^{-1}$ ) was recorded in Gogjali soil. The diffusion equation gave a higher values of rate solubility relatively to the first order equation, reached to the higher value in 
Taharawa soil ( 0.27 ) and the lowest value in Sallamiah soil ( 0.07 ). These equations are also applied on the salt affected soils as shows (table 5), that the values of sodium solubility in the first order equation were fairly similar with the soils non-affected by salts ranging ( $0.07-0.96)$.

While the values of rate solubility when apply the diffusion equation were higher in salt affected soils compared to the values in soils non-affected by salts ranged from ( $3.46-18.28$ ) which indicated that the sodium was sourced from dissolved salts, but the sodium which has dissolved or leached from soils non-affected by salts is due to the solubility of minerals bearing this element ( Sparks, 1999 and Goyal and Rani , 2011 ).

Table (4): Kinetic approach of Gapon constant due to chemical, thermodynamic , sposito concept in soils affected by salts

\begin{tabular}{|c|c|c|c|c|c|c|c|c|c|}
\hline \multirow{2}{*}{$\begin{array}{l}\text { Time } \\
\text { minute }\end{array}$} & \multicolumn{3}{|c|}{$\begin{array}{l}\text { Al-Fao } \\
\text { L.mol }^{-1}\end{array}$} & \multicolumn{3}{|c|}{$\begin{array}{c}\text { Al-Seebah } \\
\text { L.mol- }\end{array}$} & \multicolumn{3}{|c|}{$\begin{array}{c}\text { Abu- Al-Khaseeb } \\
\text { L.mol }^{-1}\end{array}$} \\
\hline & $\mathrm{K}_{\mathrm{G}}$ & $\mathrm{K}_{\mathrm{G}^{-}}^{-}$ & $\mathrm{K}_{\mathrm{G}}=$ & $\mathrm{K}_{\mathrm{G}}$ & $\mathrm{K}_{\mathrm{G}^{-}}^{-}$ & $\mathrm{K}_{\mathrm{G}}=$ & $\mathrm{K}_{\mathrm{G}}$ & $\mathrm{K}_{\mathrm{G}^{-}}^{-}$ & $\mathrm{K}_{\mathrm{G}}=$ \\
\hline 10 & 0.03 & 0.01 & 37.04 & 0.03 & 0.01 & 29.36 & 0.04 & 0.02 & 32.83 \\
\hline 20 & 0.05 & 0.03 & 29.95 & 0.05 & 0.02 & 19.86 & 0.04 & 0.02 & 31.48 \\
\hline 30 & 0.12 & 0.08 & 18.25 & 0.12 & 0.07 & 11.37 & 0.06 & 0.04 & 24.80 \\
\hline 60 & 1.03 & 0.22 & 12.64 & 0.35 & 0.13 & 7.20 & 0.13 & 0.07 & 15.33 \\
\hline 90 & 1.55 & 0.51 & 9.94 & 1.47 & 0.26 & 2.80 & 2.51 & 0.23 & 9.23 \\
\hline 120 & 2.68 & 0.86 & 5.25 & 1.67 & 1.31 & 1.71 & 2.35 & 1.15 & 4.63 \\
\hline 180 & 7.15 & 1.55 & 4.03 & 1.87 & 1.57 & 0.82 & 2.50 & 1.07 & 1.98 \\
\hline 240 & 19.79 & 4.22 & 2.12 & 1.88 & 3.31 & 0.74 & 3.43 & 1.15 & 1.31 \\
\hline 360 & 27.61 & 16.41 & 0.94 & 2.83 & 9.14 & 0.74 & 3.75 & 4.53 & 0.77 \\
\hline 480 & 39.43 & 27.85 & 0.52 & 6.71 & 17.52 & 0.67 & 5.61 & 8.62 & 0.63 \\
\hline 600 & 41.24 & 35.50 & 0.47 & 10.61 & 19.33 & 0.68 & 7.26 & 13.57 & 0.50 \\
\hline 720 & 48.83 & 37.80 & 0.35 & 12.44 & 26.72 & 0.67 & 9.33 & 19.40 & 0.50 \\
\hline
\end{tabular}

\section{Mathematical description of sodium kinetic solubility:}

The coefficient limitation $\left(\mathrm{R}^{2}\right)$ and standard error ( SE ) were used to evaluate and descripe the kinetic equations in order to descripe the best equation of sodium behavior of sodium in these soils. 
Table (5): Rate coefficient of sodium solubility by using first order and diffusion equation

\begin{tabular}{|c|c|c|c|c|}
\hline \multicolumn{5}{|c|}{ Non-affected soils } \\
\hline \multirow{2}{*}{ Locations } & \multicolumn{2}{|r|}{ First order } & \multicolumn{2}{|r|}{ Diffusion } \\
\hline & slope & Linear regression & slope & Linear regression \\
\hline Gogjali & 0.04 & $Y=0.0004 X+0.2276$ & 0.31 & $\begin{array}{c}\mathrm{Y}=0.3102 \mathrm{X}+ \\
2.2346\end{array}$ \\
\hline Taharawa & 0.12 & $Y=0.0012 X+0.2003$ & 0.27 & $\begin{array}{c}Y=0.2797 \mathrm{X}+ \\
0.4395\end{array}$ \\
\hline Bartella & 0.05 & $Y=0.0005 X+1.9492$ & 0.10 & $\begin{array}{c}Y=0.1055 \mathrm{X}+ \\
0.2541\end{array}$ \\
\hline Karamlease & 0.05 & $Y=0.0005 X+1.155$ & 0.14 & $\begin{array}{c}Y=0.1434 X+ \\
0.1612\end{array}$ \\
\hline Abbasiah & 1.14 & $Y=0.0114 X+1.9154$ & 0.08 & $\begin{array}{c}Y=0.0864 X+ \\
0.0377\end{array}$ \\
\hline Khursibat & 0.90 & $Y=0.009 X+0.6967$ & 0.14 & $\begin{array}{c}\mathrm{Y}=0.1402 \mathrm{X}+ \\
0.5921\end{array}$ \\
\hline Filfeal & 0.95 & $Y=0.0095 X+0.4433$ & 0.18 & $Y=0.1829 X+06257$ \\
\hline Badoosh & 0.30 & $Y=0.003 X+1.2833$ & 0.10 & $\begin{array}{c}\mathrm{Y}=0.1086 \mathrm{X}+ \\
0.2379\end{array}$ \\
\hline Sallamiah & 0.05 & $Y=0.0005 X+1.8483$ & 0.07 & $\begin{array}{c}Y=0.0742 \mathrm{X}+ \\
0.0268\end{array}$ \\
\hline Hamdaniah & 0.23 & $Y=0.0023 X+1.3494$ & 0.09 & $\begin{array}{c}Y=0.0997 \mathrm{X}+ \\
0.0361\end{array}$ \\
\hline \multicolumn{5}{|c|}{ affected soils } \\
\hline \multirow{2}{*}{ Locations } & \multicolumn{2}{|r|}{ First order } & \multicolumn{2}{|r|}{ Diffusion } \\
\hline & slope & Linear regression & slope & Linear regression \\
\hline Hamdan & 0.01 & $Y=0.0177 X-3.1364$ & 3.47 & $Y=3.4723 X+23.46$ \\
\hline Al-Fao & 0.04 & $Y=0.0459 X-6.7524$ & 13.09 & $Y=13.09 X+1288.2$ \\
\hline Al-Seebah & 0.18 & $Y=0.188 X-8.3067$ & 3.46 & $\begin{array}{c}\mathrm{Y}=3.4665 \mathrm{X}+ \\
578.05\end{array}$ \\
\hline $\begin{array}{l}\text { Abu- Al- } \\
\text { Khaseeb }\end{array}$ & 0.96 & $Y=0.965 X-7.72$ & 18.28 & $\begin{array}{c}\mathrm{Y}=18.285 \mathrm{X}+ \\
1050.9\end{array}$ \\
\hline
\end{tabular}


Table (6): Regression analysis of the best kinetic equation used to descripe sodium solubility

\begin{tabular}{|c|c|c|c|c|}
\hline \multicolumn{5}{|c|}{ Non-affected soils } \\
\hline \multirow{2}{*}{ Locations } & \multicolumn{2}{|c|}{ First order } & \multicolumn{2}{|c|}{ Diffusion } \\
\hline & $\mathrm{R}^{2}$ & SE & $\mathrm{R}^{2}$ & SE \\
\hline Gogjali & 0.97 & 4.22 & 0.81 & 3.00 \\
\hline Taharawa & 0.94 & 3.87 & 0.95 & 0.93 \\
\hline Bartella & 0.97 & 1.11 & 0.85 & 0.99 \\
\hline Karamlease & 0.89 & 1.27 & 0.97 & 0.42 \\
\hline Abbasiah & 0.85 & 4.51 & 0.98 & 0.14 \\
\hline Khursibat & 0.98 & 1.50 & 0.96 & 0.28 \\
\hline Filfeal & 0.98 & 1.48 & 0.94 & 0.69 \\
\hline Badoosh & 0.96 & 0.49 & 0.98 & 2.99 \\
\hline Sallamiah & 0.74 & 1.04 & 0.96 & 0.15 \\
\hline Hamdaniah & 0.89 & 0.73 & 0.97 & 0.22 \\
\hline \multicolumn{5}{|c|}{ affected soils } \\
\hline \multirow{2}{*}{ Locations } & \multicolumn{2}{|c|}{ First order } & \multicolumn{2}{|c|}{ Diffusion } \\
\hline & $\mathrm{R}^{2}$ & SE & $\mathrm{R}^{2}$ & SE \\
\hline Hamdan & 0.90 & 8.40 & 0.95 & 7.94 \\
\hline Al-Fao & 0.93 & 6.13 & 0.87 & 5.24 \\
\hline Al-Seebah & 0.90 & 7.92 & 0.98 & 6.60 \\
\hline $\begin{array}{l}\text { Abu- Al- } \\
\text { Khaseeb }\end{array}$ & 0.90 & 9.12 & 0.96 & 5.12 \\
\hline
\end{tabular}

The results ( Table 6 ) showed that the values of $R^{2}$ in the non-affected soils by salts ranged from $(0.74-0.98)$ and $\mathrm{SE}$ between $(0.49-4.51)$ in the first order equation, while the values of $R^{2}$ in the diffusion equation between $(0.85-0.98)$ and SE between $(0.14-3.00)$. Referring to soils affected by salt it was observed that the values of $R^{2}$ were between $(0.90-0.93)$ and $S E$ between $(6.13-9.12)$ in the case of the first order equation, but the values of $\mathrm{R}^{2}$ at diffusion equation are ( $0.87-0.98)$ with standard error $(5.12-7.94)$. Results indicated that the diffusion equation gave the best description for sodium solubility because it take the highest coefficient determination $\mathrm{R}^{2}$ and least standard error compared to the first order equation in all soil affected and non-affected by salts, these results were agreement with previous studies that used kinetic approach ( diffusion equation) to descripe the sodium solubility especially in salt affected soils because the reaction controlled by two ways, rate of reaction and pathway of reaction that happen to salts containing sodium ( Buentt, 1986 and Sparks , 1989). 


\section{حركيات وصف سلوك الصوديوم في بعض الترب المتأثرة وغير المتأثرة بالاملاح

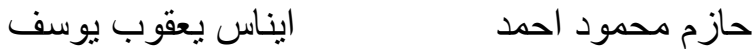 \\ جامعة الموصل، كلية الزر اعة واحمد والغابات، قسم علوم التربة و الموارد المبائية Email:Hazim572000@yahoo.com}

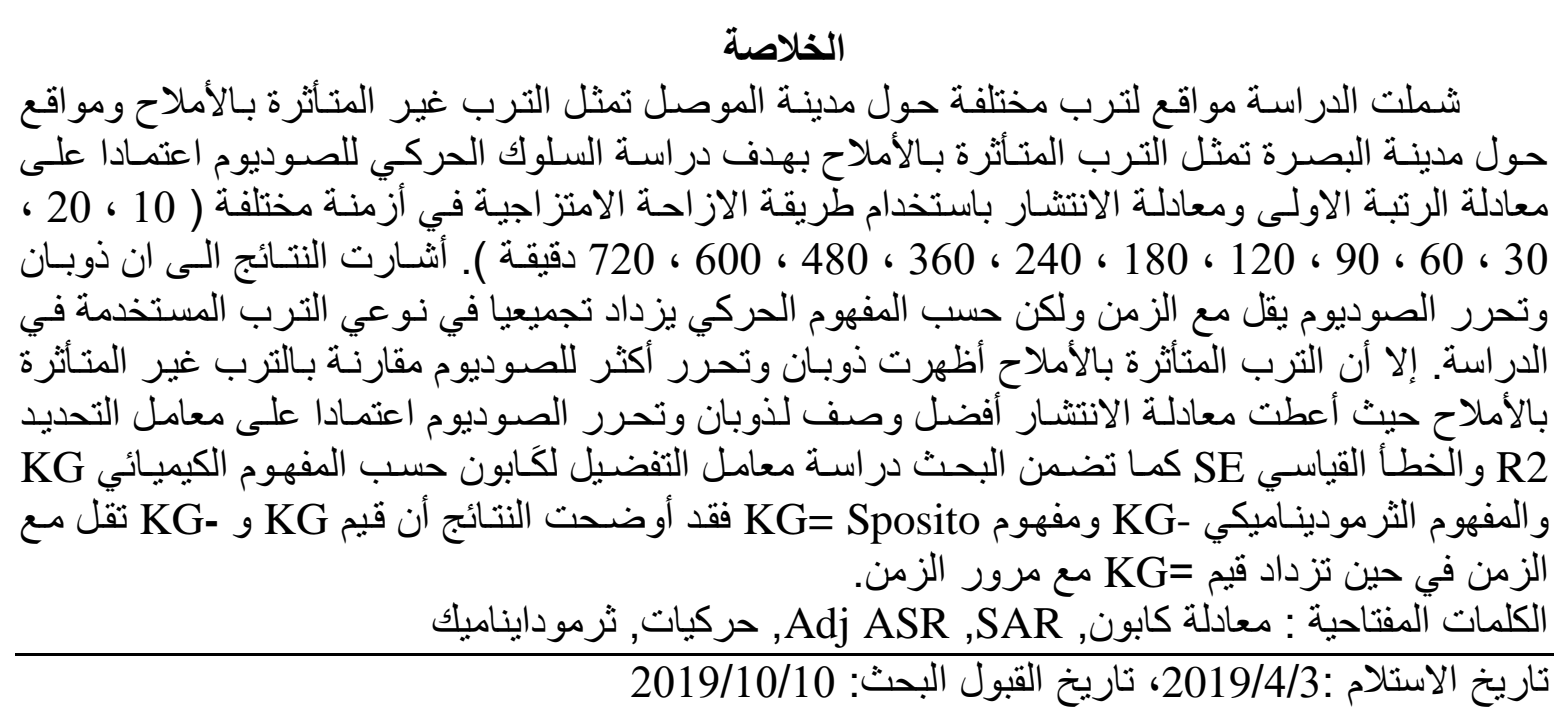

\section{REFERENCES}

Abdul- Gafoor , A., K. Hina and G. Murtaza . (2004). Estimation of Gapon exchange coefficient for different textural soils and land forms of Punjab, Pakistan . Pak. J . Agri . Sci .41:1-4.

Amrhien, C. and D.L. Suarez .(1991). Sodium-Calcium exchange with anion exclusion and weathering corrections. Soil Sci. Soc. Am. J. 55: 698- 706.

Bunett , J.F. (1986). Kinetic in solution In: " Kinetic of Soil Chemical Processes". D.L. Sparks (ed.), Academic Press, Inc. New York.

Carter, M.R. and E. G. Gregorich. (2008). Soil Sampling and Methods of Analysis. Lewis Publishers. Canadian Society of Soil Science. CRC, Press. Inc. Canada.

Farahmand A., S.Ostan , A. Jafarzadeh and N. Aliasgharazd. (2009). Estimation of Gapon selectivity coefficient for $\mathrm{Na} / \mathrm{Ca}+\mathrm{Mg}$ exchange in some saltaffected soil of Tabriz plain. Iranian Journal of Soil and Water Research. 20:17-27.

Goyal , D. and A. Rani. (2011). Leaching kinetic of $\mathrm{Na}$ in alkaline soil of kota , Rajasthan under the influence of adsorption-desorption. Int. J. Chem. Sci. 9: 35-43.

Jurinak, J.J. C. Amrhein, and R. J. Wagenet. (1984). Sodic hazard: the effect of SAR and salinity in soils and overburden materials. Soil Sci. 137:152-158.

Ogwada, R.A. and D.L. Sparks. (1986). Acritical evaluation on the use of kinetics for Determing thermodynamic of ion exchange. Soil Sci. Soc. Am. J. 50:300-305. 
Paliwal, K.V. and A.P. Gandhi.(1976). Effect of salinity SAR. Ca:Mg ratio in irrigation water and soil texture on the predictability of exchangeable sodium percentage. Soil Sci. 122: 85-90.

Rowell , D.L. (1996). Soil Science Methods and Application. Welsy, Longman , London

Sparks , D.L., L.W. Zelazny and D.C. Matens. (1980 b). Kinetics of potassium desorption in soil using miscible displacement. Soil Sci. Soc. Am. J. 44: 1205-1208.

Sparks , D.L.(1989). Kinetics of Soil Chemical Processes. Academic Press, San Diego , CA.

Sparks, D.L. (1999). Soil Physical Chemistry. Second edition. Univ. of Delaware, CRC, Press.

Sposito , G. (1977). Gapon and vanselow selectivity coefficient. SSSA. 41: 12051206.

Tandon , T.I.S. (1999). Methods of Soil Analysis, Plants, Water and Fertilizer.Fertilizer Development and Consaltation Organization, New Delhi , India.

Thomas , G.W.(1977). Historical developments in soil chemistry: Ion exchange. Soil Sci. Soc. Am. J., 41: 230-238. 